\title{
Edukasi Dokter kepada Pengonsumsi Jamu Kemasan sebagai Obat Penghilang Lelah
}

\author{
Milania Dwi Arwinda \\ Prodi Kedokteran, Fakultas Kedokteran, \\ Universitas Sebelas Maret, Surakarta, Indonesia \\ mdarwinda@student.uns.ac.id
}

\begin{abstract}
Jamu or Indonesian traditional medicine is very popular among society. The demand enhancement of jaтu brought industrial world to develop jamu into modern and instant form. They can give a low-cost and society friendly. Researchers also do researches to find out if there are substances that are not allowed to be included. Researchers also have result of their research that majority of instant jamu in society have composition of chemical substances such as corticosteroid, paracetamol, and mefenamic acid. Those compounds are very dangerous to be consumed in long-term period due to the side effects which are able to deliver metabolism abnormalities. People among society, especially in village, have no awareness in consuming that instant jamu. So that, doctor has a major role to deliver education to those people in order to decrease risk factor of metabolism abnormalities in the future.
\end{abstract}

Keywords: jamu, traditional medicine, chemical substances, side effects, patient education

\section{PENDAHULUAN}

Kelelahan berasal dari kata lelah yang berarti kehabisan tenaga (krn baru bekerja berat, berjalan jauh, dsb) penat; letih; payah; lesu; tidak bertenaga. Sehingga kelelahan bisa diartikan sebagai suatu keadaan di mana seseorang merasa penat, letih, payah, lesu, dan tidak bertenaga selepas melakukan aktivitas fisik atau bekerja (Badan Pengembangan dan Pembinaan Bahasa Kemendikbud RI, 2016). Manusia merupakan makhluk hidup yang memiliki ambang batas kemampuan untuk melakukan sesuatu sampai akhirnya terjadi kelelahan. Setiap orang memiliki ambang batas kemampuan yang berbeda-beda.

Di sisi lain, pekerjaan-pekerjaan berat yang sangat bergantung pada sumber daya manusia seolah-olah menekankan bahwa pekerja harus selalu bisa melakukan dan menyelesaikan pekerjaannya dengan maksimal. Padahal, seperti yang tersebut di atas bahwa setiap orang memiliki ambang batas kemampuan dalam melakukan suatu pekerjaan sebelum akhirnya terjadi kelelahan.

Secara fisiologis, tubuh akan mengembalikan ke keadaan semula. Namun, tubuh butuh waktu untuk mengembalikan keadaan tersebut dan harus disertai istirahat yang cukup. Sementara, pekerjaan telah menuntut mereka untuk bisa mengembalikan kebugaran mereka dengan cepat.

Banyak pekerja yang akhirnya mencari cara untuk memulihkan kelelahannya dengan cepat. Masyarakat awam lebih memilih cara tradisional seperti mengonsumsi jamu untuk memulihkan kebugarannya. Mereka menganggap bahwa jamu tidak memiliki efek samping negatif pada tubuh sehingga aman untuk dikonsumsi jangka panjang.

Jamu merupakan obat tradisional yang berasal dari Indonesia. Menurut UU RI nomor 36 tahun 2009 tentang kesehatan menyebutkan bahwa obat tradisional adalah bahan atau ramuan bahan yang berupa bahan tumbuhan, bahan hewan, bahan mineral, sediaan sarian (galenik), atau campuran dari bahan tersebut yang secara turun temurun telah digunakan untuk pengobatan, dan dapat diterapkan sesuai dengan norma yang berlaku di masyarakat.

Pada awalnya mereka mengonsumsi jamu yang dari tanaman-tanaman herbal yang mereka olah sendiri. Seiring berjalannya waktu, kebutuhan pasar terhadap jamu meningkat, memicu 
produsen untuk menciptakan jamu instan dalam bentuk kemasan sehingga konsumen tidak perlu mengolah tanaman-tanaman herbal sendiri (Sholikhah, 2016). Ditambah lagi, produsen juga menuliskan khasiat spesifik untuk tiap kemasannya.

Munculnya jamu kemasan atau jamu instan ini juga akhirnya menyebabkan munculnya peraturan-peraturan yang dibuat pemerintah untuk memastikan bahwa obat tradisional tersebut aman dan layak untuk dikonsumsi masyarakat. Jamu kemasan yang beredar di pasaran harus memiliki izin edar (Menteri Kesehatan Republik Indonesia, 2012). Selain itu, jamu kemasan tidak boleh mengandung bahan kimia obat (BKO) (Badan Pengawas Obat dan Makanan, 2013). Bahan kimia obat yang paling banyak ditambahkan ke dalam jamu tradisional adalah obat golongan kortikosteroid (dexamethasone, prednisone, phenylbutazone, methampyrone), Parasetamol, dan Asam Mefenamat (Badan Pengawas Obat dan Makanan, 2013). Jika meminum obat tradisional menimbulkan efek yang cepat, patut dicurigai ada penambahan bahan kimia obat, karena seharusnya obat tradisional atau jamu memiliki efek yang bertahap (Badan Pengawas Obat dan Makanan, 2015).

Tantangan yang dihadapi masyarakat adalah bahan kimia obat yang ada di dalam jamu kemasan terkadang tidak tertulis dalam komposisi. Bahan kimia obat baru bisa dideteksi melalui suatu prosedur bernama spektrofotodensitometri (Wisnuwardhani, Fidrianny, \& Ibrahim, 2013). Padahal, badan kimia obat yang terkandung dalam jamu dikonsumsi terus menerus maka akan timbul banyak penyakit (Badan Pengawas Obat dan Makanan, 2015).

Salah satu tugas seorang dokter yang ada di tengah masayarakat adalah mengedukasi masyarakat yang masih awam terhadap adanya bahan kimia obat yang terdapat pada jamu kemasan. Hal tersebut dimaksudkan agar tidak ada kerugian yang dirasakan masyarakat di kemudian hari. Dalam menjalankan tugas tersebut, dokter memerlukan suatu keahlian yaitu komunikasi efektif (Ha et al., 2010). Dalam artikel ini peneliti membawa rumusan masalah mengenai bagaimana edukasi yang diberikan dokter kepada masyarakat yang mengonsumsi jamu penghilang lelah secara terusmenerus.

\section{METODE}

Metode yang digunakan dalam penelitian ini adalah metode kualitatif berupa deskriptif analitik. Penelitian dilakukan dengan cara wawancara kepada masyarakat yang mengonsumsi jamu kemasan berkepanjangan sebagai penghilang lelah untuk mengetahui pengalamannya. Selain itu peneliti juga mewawancarai dokter mengenai edukasi yang tepat kepada masyarakat yang mengonsumsi jamu kemasan berkepanjangan sebagai penghilang.

\section{HASIL DAN PEMBAHASAN}

Wawancara kepada pengonsumsi jamu kemasan berkepanjangan sebagai penghilang lelah dilakukan yaitu Bapak Suparno pada Senin, 17 Juni 2019. Bapak Suparno bekerja sebagai pekerja proyek.

Berdasarkan hasil wawancara, didapatkan bahwa Bapak Suparno telah rutin mengonsumsi jamu kemasan untuk menghilangkan lelah sejak 2-3 tahun yang lalu. Alasan utama bapak tersebut terus mengonsumsi jamu kemasan adalah karena harga jamu kemasan murah serta efek kerjanya yang cepat. Bapak Suparno juga mengatakan jika rasa lelahnya tidak hilang dan timbul demam, beliau baru datang menemui dokter. Saat bertemu dengan dokter, selain diberi obat, Bapak Suparno juga diberi nasihat untuk memperbaiki pola hidup, mulai dari istirahat yang cukup, minum air yang cukup, makan makanan yang bergizi, serta berolahraga yang teratur.

Kemudian peneliti juga meminta kemasan dari jamu tersebut. Berdasarkan data yang diperoleh dari bungkus Jamu Kemasan untuk menghilangkan lelah, didapatkan komposisi sebagai berikut:

- Retrofracti fructus $0,56 \mathrm{~g}$

- Eucalypti fructus $0,84 \mathrm{~g}$

- Zingiberis aromaticae R. 0,84 g

- Zingiberis rhizoma 0,56 g

- Curcumae rhizoma 0,56 g dan

- bahan lain hingga 3,36 g. 
Retrofracti fructus (cabe jawa). Retrofracti fructus apabila dikonsumsi memiliki khasiat untuk menghilangkan dingin, menghilangkan sakit, dan meningkatkan stamina (Hariana, 2013; Herlambang \& Pradipta, 2018). Retrofracti fructus memiliki kandungan berupa piperine yang memiliki efek mirip aphrodisiac yang merupakan derivat steroid, saponins, alkaloid, tannin, dan bahan lain yang bisa meningkatkan sirkulasi darah. Efek tersebut tidak baik apabila dikonsumsi dalam waktu yang lama karena dapat menyebabkan kelainan metabolisme seperti peningkatan lemak di dalam darah, perlemakan hati, dan juga resistensi insulin (Herlambang \& Pradipta, 2018).

Zingiberis rhizoma (Jahe) memiliki banyak khasiat. Selain meredakan gejala-gejala pencernaan, jahe juga memiliki efek analgesik dan anti-inflamasi. Menurut penelitian yang membandingkan jahe dengan ibuprofen menujukkan bahwa jahe mampu meredakan rasa sakit dengan cara menghambat sintesis prostaglandin dalam tubuh dan menekan metabolisme asam arakidonat dengan efek samping yang lebih minimal daripada obat-obatan nonsteroidal anti-inflammatory drugs (NSAIDs) (Rayati, Hajmanouchehri, \& Najafi, 2017).

Curcuma rhizome (Kunyit) memiliki banyak khasiat dalam pengobatan diabetes, perdarahan, anemia, jaundice (penyakit kuning), batuk, dan lain-lain (Neha, Ranvir, \& Jangade, 2009). Selain itu, penelitian juga menyebutkan bahwa kunyit juga memiliki efek anti inflamasi dan analgesik. Cara kerja kunyit sebagai anti inflamasi dan analgesik adalah dengan cara menekan jaras siklooksigenase (John et al., 2009).

Beberapa penelitian menyebutkan bahwa mayoritas jamu kemasan yang beredar di pasaran mengandung bahan kimia obat seperti obat-obat golongan kortikosteroid (dexamethasone, prednisone, phenylbutazone, methampyrone), paracetamol, dan asam mefenamat (Badan Pengawas Obat dan Makanan, 2013; Widyawati, Rusdi, \& Maulana, 2015). Obat-obat golongan kortikosteroid apabila dikonsumsi dalam waktu yang lama akan mengganggu metabolisme dalam tubuh seperti gangguan system imun, hipertensi, hiperglikemia, osteoporosis, glaucoma, dan katarak (Ciriaco et al., 2013). Paracetamol merupakan obat analgesik yang aman jika dikonsumsi sesuai aturan. Apabila seseorang mengonsumsi paracetamol dalam waktu yang lama, paracetamol akan terakumulasi dalam tubuh dan menyebabkan kerusakan hati dikarenakan radikal bebas berupa $\mathrm{N}$-acetylpbenzoquinoneimine (NAPQI) tidak bisa dibersihkan oleh enzim glutation yang ada di dalam hati (Mustarichie, Ramdhani, \& Indriyati, 2017).

Selain melakukan wawancara dengan pengonsumsi jamu kemasan berkepanjangan sebagai penghilang lelah, peneliti juga melakukan wawancara kepada dr. Diah, yang merupakan dokter tetap di Puskesmas Gondangwetan, Pasuruan untuk mengetahui bagaimana dokter memberikan tanggapan serta edukasi kepada masyarakat pengonsumsi jamu kemasan berkepanjangan sebagai penghilang lelah. Wawancara dilakukan pada Selasa, 18 Juni 2019 bertempat di Puskesmas Gondangwetan, Pasuruan. Dari wawancara tersebut, dokter tersebut mengatakan bahwa

1. Mengonsumsi jamu bukanlah hal yang salah, namun ketergantungan dan konsumsi jangka panjang itulah yang menjadi masalah.

2. Walaupun pada kemasan jamu tersebut tertulis bahan-bahan alami, tentu pasti ada bahan kimia yang ditambahkan, seminimalnya pasti ada pewarna dan pengawet. Bahkan beberapa jamu kemasan setelah diteliti mengandung bahan kimia obat yang tidak boleh dikonsumsi jangka panjang

3. Apabila zat kimia yang ada pada jamu kemasan dikonsumsi berkepanjangan akan menimbulkan efek yang tidak diinginkan berupa gangguan pada organ-organ vital seperti hati, jantung, dan ginjal

Masyarakat yang masih awam mungkin mengira bahwa jamu kemasan berasal dari bahan herbal murni yang tidak mengandung bahan kimia berbahaya. Di sinilah tugas seorang dokter untuk memberikan edukasi kepada masyarakat untuk tidak mengonsumsi jamu kemasan tersebut dalam waktu yang lama. Dokter Diah mengatakan bahwa untuk mengedukasi pasien atau masyarakat dengan kebiasaan tersebut harus dilakukan pelan-pelan, menjelaskan apa yang terkandung dalam jamu kemasan tersebut dan menjelaskan efek sampingnya. Selain itu, dr. Diah memberi edukasi kepada masyarakat yang merasa lelah untuk mengambil waktu istirahat, meminum air yang cukup serta berolahraga yang teratur.

Kemampuan berkomunikasi merupakan suatu elemen penting yang harus dimiliki oleh seorang dokter (Chichirez \& Purcărea, 2018). Bahkan Institute of Medicine's "quality chasm" mengatakan bahwa 1 dari 6 elemen penyedia pelayanan kesehatan adalah kemampuan berkomunikasi (Epstein \& Street, 2011). Studi mengatakan bahwa hubungan komunikasi yang baik 
antara dokter pasien memiliki pengaruh yang besar dalam mengatur emosi pasien serta memberi pemahaman lebih kepada dokter untuk penegakan diagnosis yang tepat (Ha et al., 2010)

\section{SIMPULAN}

Setelah dilakukan wawancara dan analisis, dapat disimpulkan bahwa alasan masyarakat masih sering mengonsumsi jamu kemasan dikarenakan harga jamu kemasan yang murah serta memberikan efek kesembuhan yang cepat. Selain itu dari hasil penelitian yang lain, didapatkan bahwa banyak jamu kemasan anti lelah yang mengandung bahan kimia obat yang memiliki efek samping yang sangat buruk bagi tubuh apabila dikonsumsi dalam jangka waktu yang lama. Peran dokter dalam pemberian edukasi kepada masyarakat pengonsumsi jamu kemasan sebagai penghilang lelah sangat penting untuk menghindari efek samping yang tidak diinginkan.

\section{SARAN}

Masyarakat yang saat ini masih mengonsumsi jamu kemasan secara terus-menerus sebagai penghilang lelah diharapkan mulai waspada dan mulai mengurangi konsumsi jamu kemasan berlebihan. Rasa lelah adalah hal yang normal dirasakan setiap orang dan merupakan sinyal dari tubuh unuk beristirahat. Istirahat bukan pada kuantitasnya namun kualitasnya. Tidur 10 menit yang berkualitas lebih baik daripada tidur 1 jam namun tidak berkualitas. Selain itu, untuk meningkatkan tingkat kebugaran, masyarakat perlu merubah pola hidup, seperti rutin berolahraga, mengonsumsi air minimal delapan gelas per hari, serta mengonsumsi makanan-makanan bergizi seimbang.

\section{DAFTAR PUSTAKA}

\section{Buku}

Badan Pengawas Obat dan Makanan. (2015). Materi Edukasi Tentang Peduli Obat dan Pangan Aman. Badan POM.

Hariana, D. D. H. A. (2013). 262 Tumbuhan Obat dan Khasiatnya (S. Nugroho, Ed.). Jakarta: Penebar Swadaya.

\section{Jurnal}

Chichirez, C., \& Purcărea, V. (2018). Interpersonal communication in healthcare. Journal of Medicine and Life, 11(2), 119-122.

Ciriaco, M., Ventrice, P., Russo, G., Scicchitano, M., Mazzitello, G., Scicchitano, F., \& Russo, E. (2013). Corticosteroid-related central nervous system side effects. Journal of Pharmacology \& Pharmacotherapeutics, 4(Suppl 1), S94-8. https://doi.org/10.4103/0976-500X.120975

Epstein, R. M., \& Street, R. L. (2011). The Values and Value of Patient-Centered. 9(2), 100-103. https://doi.org/10.1370/afm.1239.atient-centered

Ha, J. F., Hons, M., Anat, D. S., Longnecker, N., Charles, S., \& Hospital, G. (2010). Doctor-Patient Communication: A Review. 38-43.

Herlambang, T., \& Pradipta, G. D. (2018). Javanese Long Pepper 's Extract as Alternative Energy on Sport for Gymnastics in Central Java. 247(Iset), 560-564.

John, S., Nikhil, S., Yaswanth, J., Bhaskar, A., Amit, A., \& Sudha, S. (2009). Analgesic property of different extracts of Curcuma longa (Linn .): An experimental study in animals. 9, 116-120.

Mustarichie, R., Ramdhani, D., \& Indriyati, W. (2017). Analysis of Forbidden Pharmaceutical Compouinds in Antirheumatic Jamu. Asian Journal of Pharmaceutical and Clinical Research, 10(4), 98. https://doi.org/10.22159/ajpcr.2017.v10i4.16101

Neha, S., Ranvir, G. D., \& Jangade, C. R. (2009). Analgesic and antipyretic activities of curcuma longa rhizome extracts in wister rats. Veterinary World, 2(8), 304-306. 
Rayati, F., Hajmanouchehri, F., \& Najafi, E. (2017). Comparison of anti-inflammatory and analgesic effects of Ginger powder and Ibuprofen in postsurgical pain model: A randomized, doubleblind, case-control clinical trial. Dental Research Journal, 14(1), 1-7. Retrieved from http://www.ncbi.nlm.nih.gov/pubmed/28348610

Sholikhah, E. N. (2016). Indonesian medicinal plants as sources of secondary metabolites for pharmaceutical industry. Journal of Thee Medical Sciences (Berkala Ilmu Kedokteran) Medical Sciences (Berkala Ilmu Kedokteran), 48(04), 226-239. https://doi.org/10.19106/jmedsci004804201606

Widyawati, E., Rusdi, B., \& Maulana, T. I. (2015). Identifikasi Kandungan Kortikosteroid (Deksametason, Fenilbutason, Dan Prednison) Dalam Kandungan Jamu Pegal Linu Yang Beredar Di Empat Pasar Kota Bandung 1,2,3. Prosiding Penelitian SPeSIA Unisba 2015.

Wisnuwardhani, H. A., Fidrianny, I., \& Ibrahim, S. (2013). METHOD DEVELOPMENT FOR SIMULTANEOUS ANALYSIS OF STE ROID AND NON STEROID ANTIINFLAMATORY SUBSTANCES IN JAMU PEGAL LINU USING TLCSPECTROPHOTODENSITOMETRY. Int.J.Pharm.Pharm.Sci., 5(4), 749-753.

\section{Web}

Badan Pengawas Obat dan Makanan. (2013). Hasil Pengawasan Obat Tradisional Mengandung Bahan Kimia Obat. Retrieved June 23, 2019, from https://www.pom.go.id/new/view/more/pers/96/Hasil-Pengawasan-Obat-TradisionalMengandung-Bahan-Kimia-Obat.html

Badan Pengembangan dan Pembinaan Bahasa Kemendikbud RI. (2016). Hasil Pencarian "Lelah" KBBI Daring. Retrieved from https://kbbi.kemdikbud.go.id/entri/persatuan

Menteri Kesehatan Republik Indonesia. (2012). Peraturan Menteri Kesehatan Republik Indonesia Nomor 7 Tahun 2012 Tentang Registrasi Obat Tradisional. 